Kass, the council's chairman, demanded a public apology. Kass accused the school of trying to conceal the nature of stem cell research and mischaracterizing the council's views. "Stanford has decided to proceed with cloning research without public scrutiny and deliberation, and has hurt the cause of public understanding of this subject," said Kass.

Stanford apologized. "We do plan to carefully follow all federal guidelines in our work and to adhere to the highest ethical principles and practices," said Philip Pizzo, dean of Stanford University's medical school. Pizzo says that the public "is quite confused by the word cloning." In a 17 December 2002 editorial published in the San Jose Mercury News, Pizzo wrote, "to the scientist, 'cloning' means creating an identical copy of a cell. To the public, the word often means creation of a new human life, to which scientists at the University are unanimously opposed."

Pizzo acknowledges that eventually, the institute does plan to create new embryonic stem cell lines from both mouse and human nuclei. Although federal legislation requires that public funding only be used for research on the 70-some existing human embryonic stem cell lines, California recently passed a law that allows state funding to be used to develop new lines.

Weissman disapproves of the council's use of the term, "cloning for biomedical research." "This is just a political term-it doesn't tell you what technique is actually being done," he says. Most researchers agree that the procedure used to create stem cells, which is currently called 'therapeutic cloning', should instead be

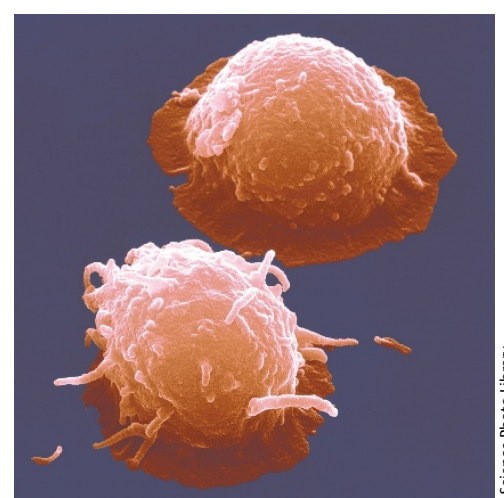

Stanford stem cell spat turns hairy plore the roles of organ-derived stem cells in tissue regeneration. "These cells can regenerate the hematopoietic system, as well as the nervous system, muscle, liver and maybe skin," says Weissman. Researchers will be studying whether these stem cells can be induced to re-grow tissue destroyed by ablative cancer therapies.

The medical center needs to raise $\$ 120$ million to complete the institute. Research will initially focus on cancer because much is already known named 'nuclear transplant to produce pluripotent stem cell lines', to describe the exact procedure.

The debate over terminology has detracted from the main research goals of the new institute. "The Associated Press seized on a very minor part of the story," says Weissman, "and the primary focus of the institute got lost in the shuffle." A priority will be to excells and tumor development. Another priority will be to compare the selfrenewal capacity of cancer cells with that of normal stem cells to determine whether cancer cells proliferate because they re-activate genes that were used by their stem cell predecessors.

Kris Novak, San Francisco about the relationship between stem

\title{
American universities operate fewer industry trials
}

If not finished, then academia's love affair with industry-sponsored trials in the United States is certainly cooling. According to CenterWatch, the independent clinical trials monitor, academic health centers (AHCs) conducted $36 \%$ of industry-sponsored trials in 2001, down from 50\% in 1996 and $71 \%$ in 1991 . Whereas AHCs once coveted industry trials as a major source of revenue, it seems that increasing funds from the National Institutes of Health and potential conflicts with overbearing industrial sponsors make the liaisons less attractive.

Academic researchers often find the sponsor's budget too low to cover study costs, and there are growing complaints that the studies being offered have lost their scientific appeal. A recent review of research at the University of Minnesota found that many industrial studies do not meet academic standards. Of the 354 clinical research proposals evaluated by the university's Research Services Office, only $62 \%$ were acceptable to investiga- tors and the institution, according to the study published in the journal Academic Medicine.

Marcia Angell, former editor of the New England Journal of Medicine, says the changes in the AHC approach are part of a backlash against the strings that are traditionally attached to industry money. "They've accepted contracts in which companies had total control over the data. Sometimes the sponsor helped write the studies," she says. "That has caused a lot of concern. I think the academic medical centers are beginning to say, 'No, we went too far.'" CenterWatch's president, Ken Getz, confirms the sea change. "In some way the academic institutions have been struggling for a while, in part because industry-sponsored research has been seen as tainted," he says.

Industry also appears to have found the relationship increasingly dissatisfying. Over the past ten years, drug companies have favored private clinical research organizations (CROs) over the more bureaucratic AHCs when seeking clinicians to test new drugs. AHCs' internal review boards tend to be slow, whereas sponsors face no opposition from CROs in retaining control of data and editing journal submissions. Some of the inefficiencies at academic centers stem from oversight systems designed to protect patients, says William Rodriguez, chief medical editor of Veritas Medical, a website that directs patients to clinical trials.

One casualty of the change is the 85member University Health system Consortium, which has been forced to drop its plans to coordinate large multi-center trials. "For the last five years, we've seen the ascension of the for-profit CROs and we found that we just couldn't compete with them," says consortium senior director Karl Matuszewski. University administrators admit that many AHC clinical trial programs do not always meet industry's needs.

Tinker Ready, Cambridge 